\title{
Impact of External Knowledge Acquisition Strategies on Innovation: A Comparative Study Based on Dutch and Swiss Panel Data
}

\author{
Spyros Arvanitis • Boris Lokshin • \\ Pierre Mohnen • Martin Woerter
}

Published online: 1 February 2015

(C) Springer Science+Business Media New York 2015

\begin{abstract}
In this paper we empirically investigate the impact of two external knowledge acquisition strategies - 'buy' and 'cooperate' —on firm's innovation performance. Taking a direct (productivity) approach, we test for complementarity effects in the simultaneous use of the two strategies, and in the intensity of their use. Our resultsbased on panels of Dutch and Swiss innovating firms — suggest that while both 'buy' and 'cooperate' have a positive effect on innovation, there is little statistical evidence that using them simultaneously leads to higher innovation performance. Results from the Dutch sample provide some indication that there are positive economies of scope in doing external and cooperative R\&D simultaneously.
\end{abstract}

Keywords Open innovation $\cdot R \& D$ collaboration $\cdot$ Make and buy strategies JEL Classification $\mathrm{O} 31 \cdot \mathrm{O} 32$

S. Arvanitis $(\varangle) \cdot$ M. Woerter

KOF Swiss Economic Institute, ETH Zurich, 8092 Zurich, Switzerland e-mail: arvanitis@kof.ethz.ch

M. Woerter

e-mail: woerter@kof.ethz.ch

B. Lokshin

Maastricht University, P.O. Box 616, 6200 MD Maastricht, The Netherlands

e-mail: b.lokshin@maastrichtuniversity.nl

P. Mohnen

Maastricht University and UNU-MERIT, P.O. Box 616, 6200 MD Maastricht, The Netherlands e-mail: p.mohnen@maastrichtuniversity.nl 


\section{Introduction}

This is a paper on the impact of external knowledge acquisition strategies on innovation performance and is mainly motivated by the observation of the necessity of the acquisition of new knowledge as a precondition for successful innovative activities of enterprises. In addition to their own research and development (internal R\&D) enterprises typically are engaged in the trading of knowledge on the technology market (contract or external R\&D) and/or cooperate actively - formally or informally-with other firms and research institutions.

For applied industrial economics an important task is an understanding of how firms integrate internal knowledge and various types of externally acquired knowledge and if such activities increase firms' performance. An important motive for this research interest is the improvement of our understanding of the role of such strategies with respect to the innovation performance of enterprises that engage in such strategies (see Cassiman and Veugelers 2006; Belderbos et al. 2006). Better insights into knowledge acquisition strategies and their impact on innovation would allow the formulation of a knowledge-based technology policy. We focus in the paper at hand on two knowledge acquisition strategies: external or contract R\&D and R\&D (innovation) cooperation. Further, we use data for more than one cross-section and try to tackle the problem of potential endogeneity of the knowledge strategies, which is an issue that has been scarcely addressed until now in the literature (see, e.g., Cassiman and Veugelers 2006).

Why a comparative study of the Netherlands and Switzerland? It is interesting to investigate the impact of knowledge acquisition strategies on innovation performance for two countries that show several similarities (small open economies, technologically advanced - near the "technological frontier"), with Switzerland as an "innovation leader" and the Netherlands as an "innovation follower" according to an EIS (European Innovation Scoreboard) 2008 assessment. At the same time, there are differences that might be relevant for the outcomes of knowledge acquisition strategies: EU membership and a more active innovation policy in the Netherlands: e.g., more public support of corporate R\&D (which is almost non-existent in Switzerland) and of R\&D (innovation) cooperation.

Our study is original in two respects: First, we investigate the impact of external $R \& D$ and $R \& D$ (innovation) cooperation as well as the combined effect of these two strategies, based both on qualitative and quantitative variables that measure the two strategies and separately for manufacturing and services using three cross-sections of firm data for both countries. With one exception (Cassiman and Veugelers 2006), all other reviewed studies (see Sect. 2) investigated primarily complementarities between in-house R\&D and external (contract) R\&D but not between the external knowledge acquisition strategies (cooperation; external $R \& D$ ), which is the main subject of this study. Second, we compare two technologically advanced European countries with different innovation policies that might influence corporate strategies of knowledge acquisition.

Informed by the growing literature on open innovation (Chesbrough 2003; Dahlander and Gann 2010; Drechsler and Natter 2012; Fey and Birkinshaw 2005), we expected that the more that firms rely on different external knowledge sourcing modes, the better they would perform in terms of innovation. While we find some evidence 
that both external technology sourcing and R\&D cooperation positively impact innovation in isolation, we hardly find evidence of an additional gain in performance when both are used simultaneously.

The structure of the paper is as follows: In Sect. 2 we briefly discuss related empirical literature. Section 3 presents the model specification. Section 4 deals with the data. In Sect. 5 we discuss the method and present the results. Finally, Sect. 6 concludes.

\section{Conceptual Background}

\subsection{Internal and External Knowledge Acquisition Modes}

External modes of knowledge acquisition have advantages vis-à-vis internal strategies in terms of more efficient learning in volatile environments, but they entail also disadvantages in terms of insufficient utilization of in-house generated knowledge and insufficient protection of knowledge from competition (see, e.g., Leiponen 2005).

Extant theory in the IO literature considers a firm's knowledge absorptive capacity (Cohen and Levinthal 1989, 1990) and the extent of knowledge spillovers as important determinants of the tendency to use external modes of knowledge acquisition (De Bondt 1996; Cassiman and Veugelers 2002). The former is the ability to exploit externally generated knowledge; the latter is the amount of exploitable external knowledge that flows into (incoming spillovers) or out (outgoing spillovers) of the firm.

There is an inherent relationship between these three concepts: absorptive capacity is necessary in order to be able to exploit available external knowledge: to ensure knowledge flows to the firm (incoming spillovers: through "buy", "cooperation" or other channels); but the firm is also interested in protecting its own knowledge base from being exploited by other firms or institutions without appropriate payment for it and thus tries to keep outgoing spillovers under its control: for example, through various protection mechanisms.

With respect to incoming spillovers, external or contract R\&D ("buy") requires less absorptive capacity than does $R \& D$ cooperation. In the former case a firm needs, for example, some complementary know-how that can be supplied by some external provider at the same quality as if it was produced in house but at lower costs (which is a cost-reduction argument for outsourcing; see, e.g., Williamson 1975). ${ }^{1}$ In the latter case, for example in a R\&D joint venture, both partners are engaged in projects that generate new knowledge that can be combined with in-house R\&D to generate innovations.

Both strategies indicate a tendency to open the innovation process as compared to in-house R\&D. However, they are not identical with respect to the appropriability implications. When the buy strategy is used firms are obviously not interested in protecting the $\mathrm{R} \& \mathrm{D}$ (innovation) outcomes from competitors or keeping them secret from them.

\footnotetext{
1 The full argument is: Outsourcing can be profitable only if the expected cost advantage is higher than the sum of costs of search efforts to find a suitable supplier, the costs of related asset-specific investments and the costs of contract imperfectness.
} 


\subsection{Complementarity of Knowledge Acquisition Strategies}

In the context of this study the relevant question refers to the existence of complementarities between alternative knowledge acquisition strategies with respect to innovation performance in the framework of an innovation equation in which other factors that determine innovation (besides knowledge acquisition strategies) are controlled for.

The theoretical concept of supermodularity helps to clarify the notion of complementarity, and therefore is useful for empirical research aimed at investigating the existence of mutual reinforcement effects among economic activities (see Milgrom and Roberts 1990; Athey and Stern 1998). The main idea in its simplest form is as follows: Suppose that there are two activities $A_{1}$ and $A_{2}$. Each activity can be performed by the firm $\left(A_{i}=1\right)$ or not $(A i=0)$; $(I=1,2)$. The function $\Pi\left(A_{1}, A_{2}\right)$ is supermodular only if $\Pi(1,1)-\Pi(0,1) \geq \Pi(1,0)-\Pi(0,0)$; i.e., adding an activity while the other activity is already being performed has a higher incremental effect on performance than adding the activity in isolation. This elegant formula states the necessary conditions for activities to be complementary. This proposition can be easily generalized for more than two activities (see, e.g., Carree et al. 2011).

\section{Review of Related Empirical Literature}

We concentrate here on the line of empirical research on knowledge acquisition strategies that emphasize the performance implications of external knowledge sourcing, particularly the possible complementarity of such strategies: i.e. the mutual strengthening with respect to economic performance. Studies in this line investigate the impact on innovation performance as well as on economic performance in the narrow sense, for example, labour productivity.

Focusing on industrial research laboratories in the US, Adams and Marcu (2004) found that R\&D sourcing is mainly driven by research joint ventures with federal government institutions. Sourcing saves R\&D costs and secures access to technical services, but it does not affect innovation performance as measured by patents and new products. In contrast, internal research and research joint ventures increase innovation output.

Beneito (2006) investigated two hypotheses: (a) in-house R\&D activities are more productive in terms of significant innovations that lead to patents than is contract $\mathrm{R} \& \mathrm{D}$, which, in turn, is more productive than internal $\mathrm{R} \& \mathrm{D}$ in terms of incremental innovations that lead to utility models; (b) the composition of total R\&D investment matters. The analysis, based on longitudinal data of Spanish firms, confirms both hypotheses. Thus in-house and contract R\&D show different effects on innovation performance. In-house R\&D activities in isolation may succeed in terms of both kinds of innovation but contracted $R \& D$ does not generate significant innovations, unless it is combined with in-house activities.

Analyzing a sample of Belgian manufacturing firms Cincera et al. (2003) found that besides internal R\&D, cooperation with foreign partners-customers, suppliers or other foreign companies - seems to stimulate firm productivity growth significantly. In contrast, $R \& D$ cooperation with Belgian partners is associated with low productivity growth. 
Peeters and van Pottelsberghe de la Potterie (2006) confirmed in a study with data of Belgian firms the results of Beneito (2006) (see above) regarding the higher productivity of in-house $R \& D$ with respect to patents in comparison to contract $R \& D$. They found that the choice of a specific innovation strategy is more important than other firm or sector characteristics for explaining patent activities. Especially R\&D cooperation with external partners enhances patent activities of firms. Furthermore, firms that focus on process innovation are less likely to have patents than are productoriented innovating firms.

Cassiman and Veugelers (2006) investigated in their pioneering work on "complementarity in innovation strategy" the main drivers for internal ("make") and/or external ("buy", cooperation) knowledge acquisition strategies on Belgian manufacturing firm data. In addition, they analyzed the impact of different knowledge strategies on product innovation performance. By applying several econometric estimation methods the authors found that there exists complementarity between the strategies "make" and "buy". External knowledge shows the greatest positive impact on the innovation performance of a firm only when it is combined with internal R\&D activities. Rather surprisingly R\&D cooperation does not show the expected significant positive effect.

In a further study based on data from the German part of the Community Innovation Survey (CIS3) Schmiedeweg (2008) provided evidence for significant complementarities between internal and R\&D cooperation, but he found no complementarity between internal and $R \& D$ cooperation.

Grimpe and Hussinger (2013) investigated the complementarity effects of formal and informal technology transfer from academia to industry with respect to innovation performance. The analysis was based on a dataset of more than 2,000 German firms. The results based on direct and indirect complementarity tests showed a complementarity relationship between informal and formal technology transfer.

Based on a panel sample of 83 pharmaceutical firms covering the period 19862000, Hagedoorn and Wang (2012) found that internal and external R\&D strategies are complementary innovation activities at high levels of in-house R\&D investments, whereas at low levels of in-house R\&D efforts the two knowledge acquisition strategies are substitutive options.

In a further study based also on a panel dataset on the R\&D and in-licensing expenditures of 94 global pharmaceutical firms for the period 1997-2005, Ceccagnoli et al. (2013) found that internal R\&D and in-licensing were neither complements nor substitutes. However, the degree of complementarity was enhanced for firms with stronger absorptive capacity, economies of scope, and past licensing experience.

Existing studies referring to the Netherlands cover primarily the effects of different types of R\&D cooperation on performance. Belderbos et al. (2004) analyzed the impact of $R \& D$ cooperation on firm performance, that they differentiate between four types of R\&D partners (competitors, suppliers, customers as well as universities and research institutions), and consider two performance measures: labour productivity with respect to value added and labour productivity with respect to sales of innovative products. Competitor and supplier cooperation focus on incremental innovations that improve labour productivity based on value added. University cooperation enhances particularly productivity with respect to sales of innovative products. Furthermore, customers and universities are important sources of knowledge for firms pursuing 
radical innovations that facilitate growth of sales innovative products in the absence of formal R\&D cooperation.

In a further study based on data of Dutch firms from two surveys conducted in 1996 and 1998, Belderbos et al. (2006) assessed the performance effects of simultaneous engagement in R\&D cooperation with different partners (competitors, clients, suppliers, and universities and research institutions). They tested whether these different types of R\&D cooperation are complements in improving labour productivity. According to the results, customer cooperation helps to increase market acceptance and diffusion of product innovation and enhances the impact of competitor and university cooperation. Smaller firms face diseconomies in pursuing multiple R\&D cooperation strategies, which may stem from higher costs of simultaneously managing several partnerships.

Lokshin et al. (2008) examined the impact of internal and external R\&D on labour productivity in a six-year panel of Dutch manufacturing firms and found complementarity between internal and external $R \& D$, with a positive effect of external $R \& D$ evident only in case of sufficient internal R\&D.

Related studies referring to Switzerland investigate either the determinants of different modes of knowledge acquisition (Woerter 2011) or the specific form of cooperation between universities and corporations (e.g., Arvanitis et al. 2011), but none of them deals with the issue of complementarity between "buy strategy" and "coop strategy".

As already mentioned, with one exception (Cassiman and Veugelers 2006) to our knowledge, all other reviewed studies investigated primarily complementarities between in-house R\&D and external (contract) R\&D but not between the external knowledge acquisition strategies (cooperation; external R\&D), which is the main subject of this study. The findings vary not only by country of origin of the investigated enterprises but also by the size of the firm samples that are used for the analysis, the target performance indicators and the reference period of the data.

\section{Model Specification}

Our interest here is not to re-address the complementarity between make and buy (Bönte 2003; Cassiman and Veugelers 2006; Hagedoorn and Wang 2012; Lokshin et al. 2008), but instead to examine a possible complementarity between two external knowledge acquisition strategies: external R\&D (BUY) and cooperation (COOP), for firms that conduct internal R\&D (MAKE).

External R\&D corresponds to arm's length technology acquisition, through subcontracting and outsourcing. Collaboration refers to joint efforts, with risk-sharing, cost-sharing and knowledge-sharing. Hence the question is whether it pays to collaborate in addition to outsourcing or to outsource in addition to collaborating. We limit ourselves to firms that do internal R\&D for two reasons: ${ }^{2}$ first, because the likelihood

\footnotetext{
2 We assume that most of R\&D investment is targeted to product innovations (see the discussion in Scherer 1991). Fritsch and Meschede (2001) estimated the share of product R\&D expenditure in all R\&D in a sample of 1,800 German enterprises in the 1990 s to be about $61 \%$. For US firms in the 1970 s the share of productoriented R\&D expenditure was estimated at $68 \%$ (Scherer 1984). Based on information about 4,000 major innovations in UK manufacturing from the Second World War until 1983 reported in Pavitt et al. (1987),
} 
that firms without internal $R \& D$ engage in external $R \& D$ and $R \& D$ cooperation is nil in our samples, and second, because in this way the data for cooperation become comparable across the two countries (see also footnote 4 ).

We shall assess the existence and the extent of complementarity using the productivity approach and not the correlation approach, respectively PROD and CORR as Athey and Stern (1998) called them. The correlation approach verifies whether two strategies are adopted jointly after controlling for some other common determinants; the productivity approach tests whether the use of both strategies leads to a higher level of economic performance. It seems to us that the latter approach is more powerful as it tests directly the efficiency of using both strategies whereas the former tests only whether they are adopted jointly for reasons that cannot otherwise be explained.

We shall first test whether doing both external R\&D and collaborating leads to higher economic performance: i.e., we use only qualitative information on BUY and COOP and test complementarity using the notion of supermodularity (Milgrom and Roberts 1990).

In a second step, we also analyze the complementarity on the basis of quantitative data: the amount of external R\&D expenditure (as a share of sales) and the number of cooperation partners. Complementarity between two strategies then means that the marginal return of one strategy increases with the amount of the other strategy, where the return is defined in terms of some kind of payoff function.

We have chosen as the payoff function the amount of product innovation, which is defined as the share in total sales that is due to new-to-the-firm or essentially improved products (in short, the share of innovative sales). To capture the complementarity effect, we include an interaction term of external $R \& D$ and number of cooperation partners.

We log-transform the share of innovative sales $\left(y_{i t}\right)$ and make it depend in a linear fashion on the external knowledge acquisition strategies $\left(x_{i t}^{1}\right)$ while controlling for other determinants of innovation output $\left(x_{i t}^{2}\right)$. Formally, we have

$$
\ln y_{i t}=\alpha+\beta_{1} x_{i t}^{1}+\beta_{2} x_{i t}^{2}+u_{i}+\varepsilon_{i t},
$$

where the error term has two independent components: one firm-specific, $u_{i}$, that is assumed to be normally distributed with mean 0 and variance $\sigma_{u}^{2}$; and one idiosyncratic, $\varepsilon_{i t}$, that is assumed to be normally distributed with mean 0 and variance $\sigma_{\varepsilon}^{2}$. By allowing for an individual effect that is generated by a certain distribution (the random effect specification in panel data), we control for unobserved individual-specific determinants, which might affect the parameter estimates. The individual random effect is not correlated with the exogenous control variables $\left(x_{i t}^{2}\right)$, but might be correlated with the strategy variables $\left(x_{i t}^{1}\right)$.

\section{Footnote 2 continued}

Scherer (1991) estimated the share of product-focused R\&D expenditure of about $70 \%$. A product-R\&D expenditure share of about two thirds appears to be a structural characteristic of R\&D expenditure in most technologically advanced countries. As a consequence, we assume that the potential error in ignoring process innovation is small. In any case, at least for the Netherlands we have no quantitative measure of process innovation, and therefore we have preferred not to include this part of innovation in our analysis. 
Therefore, we resort to an instrumental variables estimator, where we project the endogenous explanatory variables on the exogenous variables of the model and a set of excluded instruments, i.e. not appearing in (1) as explanatory variables. We have decided to control for individual heterogeneity through a random effect rather than a fixed effect for three reasons: it allows us to keep enterprises with only one observation; it keeps time-invariant variables; and it does not suffer from the incidental parameters problem.

For the reasons indicated above, we run regression (1) only on firms with R\&D. Since not all innovators are internal R\&D performers, it is necessary to correct for this selection bias. To this end, we follow the Heckman two-step procedure: We first run a probit to select the firms that perform internal R\&D and derive from it an inverse Mill's ratio (IMR), which we then introduce in Eq. (1) besides $x_{i t}^{1}$ and $x_{i t}^{2}$. An additional problem is that has to be addressed is that the variable for the sales share of innovative products contains zeros. ${ }^{3}$

Whereas with the qualitative variables for BUY and COOP, internal R\&D (MAKE) serves as the reference category, in the version with quantitative variables we must also control for the amount of internal R\&D. Indeed, we can no longer ignore the fact that doing more internal R\&D may also influence the share of innovative sales. Actually, ignoring the possible effect of internal R\&D may create a serious variable omission bias. Moreover, if we assume that firms maximize their performance by choosing their strategies appropriately - and hence they maximize with respect to internal $\mathrm{R} \& \mathrm{D}$, external $\mathrm{R} \& \mathrm{D}$, and the number of cooperating partners - then, by the second-order conditions, the Hessian should be negative definite. If we exclude the own squared terms and only include the interaction terms, then the second principal minor will always have the wrong sign. Therefore, it is important to include the own squared terms in addition to the interaction terms.

Some firms may have no external R\&D or no cooperation partners. To avoid having zeros, we increase all values of external $R \& D$ and number of cooperation partners by one (one thousand actually in the case of external R\&D whose units are in thousands). These small changes should only slightly affect the marginal effects that will later be calculated.

We estimate (1) separately for Dutch firms and Swiss firms, since in any case we are not allowed for reasons of statistical confidentiality to merge and share the data, but also because the coefficients in (1) might not be the same in the two countries and because the available variables that we want to control for are sometimes measured differently in the two countries.

\footnotetext{
3 This variable for the sales share of innovative products contains zeroes because some R\&D performers are non-product innovators. They are about $15 \%$ in the Netherlands, hence we run two separate probit regressions (one for the occurrence of $\mathrm{R} \& \mathrm{D}$, as already discussed in text above, and, conditional on that, one on the occurrence of product innovation; excluded variable: "firm being part of a group") and we subsequently use the two inverse Mills ratios from these probit regressions to control for truncated distributions of the error terms in the share of innovative sales regression (see Tables 4, 5 and 6). In Switzerland there are only 108 manufacturing firms and 55 service firms that have zero value for innovation output; in sum only $6 \%$ of our 2,739 observations. Hence, it is not necessary to apply additional Mills ratios for Switzerland.
} 
Table 1 Unbalanced panel data structure

\begin{tabular}{lllllc}
\hline Pattern 1998/2000/2004 & \multicolumn{2}{c}{ Switzerland (in \%) } & & \multicolumn{2}{c}{ Netherlands (in \%) } \\
\cline { 2 - 3 } & Manufact. & Services & & Manufact. & Services \\
\hline $1-0-0$ & 18.9 & 23.5 & & 34.4 & 7.8 \\
$0-1-0$ & 24.1 & 24.1 & & 20.7 & 49.8 \\
$0-0-1$ & 21.2 & 28.8 & & 16.3 & 34.5 \\
$1-1-0$ & 9.7 & 7.6 & & 11.4 & 1.1 \\
$1-0-1$ & 5.4 & 3.8 & & 6.0 & 0.3 \\
$0-1-1$ & 10.6 & 8.7 & & 4.3 & 6.2 \\
$1-1-1$ & 10.1 & 3.4 & 6.8 & 0.8 \\
\hline
\end{tabular}

\section{Data}

In Switzerland and in the Netherlands innovation surveys have been conducted for a number of years so that panel data can be used to control for individual effects that might plague the conclusions with regard to complementarity between cooperation strategies (Miravete and Pernías 2006).

For Switzerland we rely on the waves that pertain to the years 1997-1999, 20002002 and 2003-2005 (where the level observations, like the share of innovative sales, pertain to the years 1998, 2001 and 2004 and other variables cover the entire threeyear period). For the Netherlands we use the waves pertaining to the years 1998-2000, 2000-2002 and 2002-2004 (where the level observations pertain to the years 2000, 2002 and 2004 and other variables cover the entire three-year period).

From the three waves we construct an unbalanced panel of enterprises in manufacturing and in services. The composition of the datasets by industry and firm size class are found in Table 8 in the "Appendix". For Switzerland $35.8 \%$ of manufacturing firms and $23.5 \%$ of service firms participated two or three times to the survey; the respective figures for the Netherlands are 28.5 and $8.4 \%$, respectively. Table 1 shows some more detailed information about the unbalanced nature of the panels.

In Table 2 we present the definitions and abbreviations of the variables that we use in our econometric analysis. Internal $R \& D$, external $R \& D$ and sales of new products are normalized by total sales. Cooperation is measured by the number of cooperation partners. We try to control for the same variables in the two countries, but some of them are measured differently. ${ }^{4}$

\footnotetext{
4 There are two differences with respect to the definition of the variables for external R\&D and cooperation between the Swiss and the Dutch survey questionnaire. First, in the Swiss innovation survey questionnaire external R\&D is explicitly excluded in the definition of cooperation, but this is only implicitly the case for the Dutch questionnaire. So a potential overlap between external R\&D and cooperation in the Dutch data cannot be ruled out. We assume that there are few such cases of overlap. The alternative estimates that use quantitative variables for external $R \& D$ and collaboration serve as a robustness test for the estimates that are based on the qualitative data. Second, the Swiss data refer only to R\&D cooperation, whereas the Dutch data cover also cooperation in other innovation activities (e.g., construction, design). By concentrating on firms that do internal R\&D in the Dutch survey, we minimize this difference in the definition of cooperation between the two countries because R\&D-active firms are more likely to engage in R\&D cooperation than in other innovation activities. There are further measurement differences regarding the number of cooperation partners and incoming knowledge spillovers (see Table 2).
} 
Table 2 Construction of variables

\begin{tabular}{|c|c|}
\hline Variable name & Definition \\
\hline & Dependent variable \\
\hline \multirow[t]{2}{*}{ Log Newsales } & $\begin{array}{l}\text { Natural logarithm of share in total sales of new (or } \\
\text { essentially modified)-to-firm products }\end{array}$ \\
\hline & Independent variables \\
\hline Make_d & $\begin{array}{l}\text { Dummy variable for having only intra-mural R\&D } \\
\text { expenditures }\end{array}$ \\
\hline Make & $\begin{array}{l}\text { Total intra-mural R\&D expenditures, in 1,000 Euros for the } \\
\text { Netherlands, CHF for Switzerland, divided by sales, in } \%\end{array}$ \\
\hline Buy_d & $\begin{array}{l}\text { Dummy variable for having only extra-mural R\&D } \\
\text { expenditures (in addition to intra-mural expenditures) }\end{array}$ \\
\hline Buy & $\begin{array}{l}\text { Total extra-mural (external) R\&D expenditures, in } 1,000 \\
\text { Euros for the Netherlands, CHF for Switzerland, divided } \\
\text { by sales, in } \%\end{array}$ \\
\hline Coop_d & $\begin{array}{l}\text { Dummy variable for having only R\&D (innovation) } \\
\text { cooperation with other firms, research institutions, etc. } \\
\text { (in addition to intra-mural expenditures) }\end{array}$ \\
\hline Coop & $\begin{array}{l}\text { A count of number of technology partnerships a firm } \\
\text { reported engagement in (both domestically and } \\
\text { internationally) with customers, suppliers, competitors, } \\
\text { universities, research institutes, commercial labs, } \\
\text { consultants, other enterprises within a group. For } \\
\text { Switzerland the maximum number of cooperation } \\
\text { partners is } 13 \text {, in the Netherlands it is } 25\end{array}$ \\
\hline Buy_Coop_d & $\begin{array}{l}\text { Dummy variable for having external } \mathrm{R} \& \mathrm{D} \text { expenditures and } \\
\text { cooperation (in addition to intra-mural expenditures) }\end{array}$ \\
\hline Log Size & Natural logarithm of number of employees \\
\hline$M N E$ & $\begin{array}{l}\text { Dummy variable: } 1 \text { if the headquarters of the firm are } \\
\text { located outside the Netherlands/Switzerland, else } 0\end{array}$ \\
\hline Log Age & $\begin{array}{l}\text { Natural logarithm of number of years a firm exists } \\
\text { (Excluded) Instruments }\end{array}$ \\
\hline $\begin{array}{l}\text { Incoming knowledge flows from } \\
\text { industry \& non-industry partners } \\
\text { and incoming knowledge flows } \\
\text { from public sources; for the } \\
\text { Netherlands (Spil) for Switzerland } \\
\text { (Spill) }\end{array}$ & $\begin{array}{l}\text { NL: Sum of scores of importance of information received } \\
\text { from customers, suppliers, competitors for firm's } \\
\text { innovative activities divided by the sum of scores of } \\
\text { importance of information received from public sources } \\
\text { such as patents, conferences, and trade publications } \mathrm{CH} \text { : } \\
\text { Firms were asked to assess the importance of information } \\
\text { received from competitors (Spil1) on a 5-point Likert scale }\end{array}$ \\
\hline \multirow[t]{2}{*}{$\begin{array}{l}\text { Organizational constraints related to } \\
\text { lack of qualified personnel (Hper) }\end{array}$} & $\begin{array}{l}\text { NL: Firms were asked to assess the importance of lack of } \\
\text { qualified staff as a hampering factor to innovation (3-point } \\
\text { Likert scale) }\end{array}$ \\
\hline & $\begin{array}{l}\mathrm{CH} \text { : Firms were asked to assess the importance of lack of } \\
\text { R\&D staff as a hampering factor to innovation (5-point } \\
\text { Likert scale) }\end{array}$ \\
\hline Demand development (Demand) & $\begin{array}{l}\mathrm{CH} \text { : Development of the demand during the last three years } \\
\text { (5-point Likert scale) }\end{array}$ \\
\hline Price competition (IPC) & $\begin{array}{l}\text { CH: Firms were asked to assess the importance of price } \\
\text { competition in their main product market (5-point Likert } \\
\text { scale) }\end{array}$ \\
\hline Technological potential $(T p)$ & $\begin{array}{l}\mathrm{CH} \text { : Assessment of the technological potential of the firm's } \\
\text { main business activity (5-point Likert scale) }\end{array}$ \\
\hline
\end{tabular}


Table 3 Frequency (in percentages) of knowledge acquisition strategies among internal R\&D performers

\begin{tabular}{|c|c|c|c|c|}
\hline & \multicolumn{2}{|l|}{ Switzerland } & \multicolumn{2}{|l|}{ Netherlands } \\
\hline & Manufacturing & Services & Manufacturing & Services \\
\hline $\begin{array}{l}\text { No external R\&D and no cooperation } \\
\text { (only make) }\end{array}$ & 36.1 & 41.7 & 27.3 & 20.7 \\
\hline External R\&D only (make and buy) & 29.9 & 27.2 & 33.1 & 42.6 \\
\hline Cooperation only (make and coop) & 10.0 & 11.8 & 9.3 & 6.8 \\
\hline $\begin{array}{l}\text { External R\&D and cooperation } \\
\text { (make, buy and coop) }\end{array}$ & 24.0 & 19.3 & 30.1 & 30.0 \\
\hline
\end{tabular}

In Table 3 we compare the frequencies of technology acquisition strategies for internal R\&D performers between Switzerland and the Netherlands, in manufacturing and in services. The column sums of Table 3 add up to $100 \%$. In manufacturing, the proportion of firms that rely only on internal R\&D is $33 \%$ higher in Switzerland than in the Netherlands, the proportions of firms that rely on internal R\&D and external $\mathrm{R} \& \mathrm{D}$ or on internal $\mathrm{R} \& \mathrm{D}$ and $\mathrm{R} \& \mathrm{D}$ cooperation is similar in the two countries, and the proportion of firms that use all three sources of knowledge acquisition is $24 \%$ in Switzerland compared to $30 \%$ in the Netherlands.

In services, the differences are more pronounced: In Switzerland more than twice as many firms rely on internal $R \& D$ only, almost twice as many rely on internal R\&D plus cooperation, and one third of them rely less on internal R\&D combined with either external R\&D or with external R\&D and cooperation, compared to the Dutch firms. Thus, in general the observed frequencies reveal that the Dutch firms favor open innovation more than do the Swiss firms. The fact that a higher proportion of Dutch firms practice all three types of knowledge acquisition could in part be due to a less clear definitional separation of external R\&D and cooperation.

In Table 4 we present some descriptive statistics about the quantitative variables that are used in the analysis and the instrumental variables, again separately for manufacturing and for services. The average share of innovative sales is slightly higher in Switzerland (36 versus $31 \%$ in manufacturing and $27 \%$ versus $23 \%$ in services).

In accordance with Table 2, the intensity of internal R\&D that is shown in Table 3 is substantially higher in Switzerland than in the Netherlands and in both countries higher in services than in manufacturing. In contrast, the intensity of external R\&D is substantially higher in the Netherlands compared to Switzerland. Dutch firms spend on average three times as much as Swiss firms on external R\&D in manufacturing and four times as much in services. The number of partnerships is about the same in the two countries if we normalize them by the maximum number of possible partnerships, which is almost twice as high in the Netherlands as it is in Switzerland.

In the Dutch sample there are about twice as many MNEs as in Switzerland in manufacturing and three times as many in services, which could in part explain the difference in the amount of external $R \& D$ ( $\& \& D$ performed by a subsidiary of the MNE is internal to the MNE, but here it is considered as external to the firm). The average Dutch firm is younger and slightly larger than the average Swiss firm, both in manufacturing and in services. The choice of excluded instruments used to correct for the endogeneity of technology acquisition strategies is country-specific. 


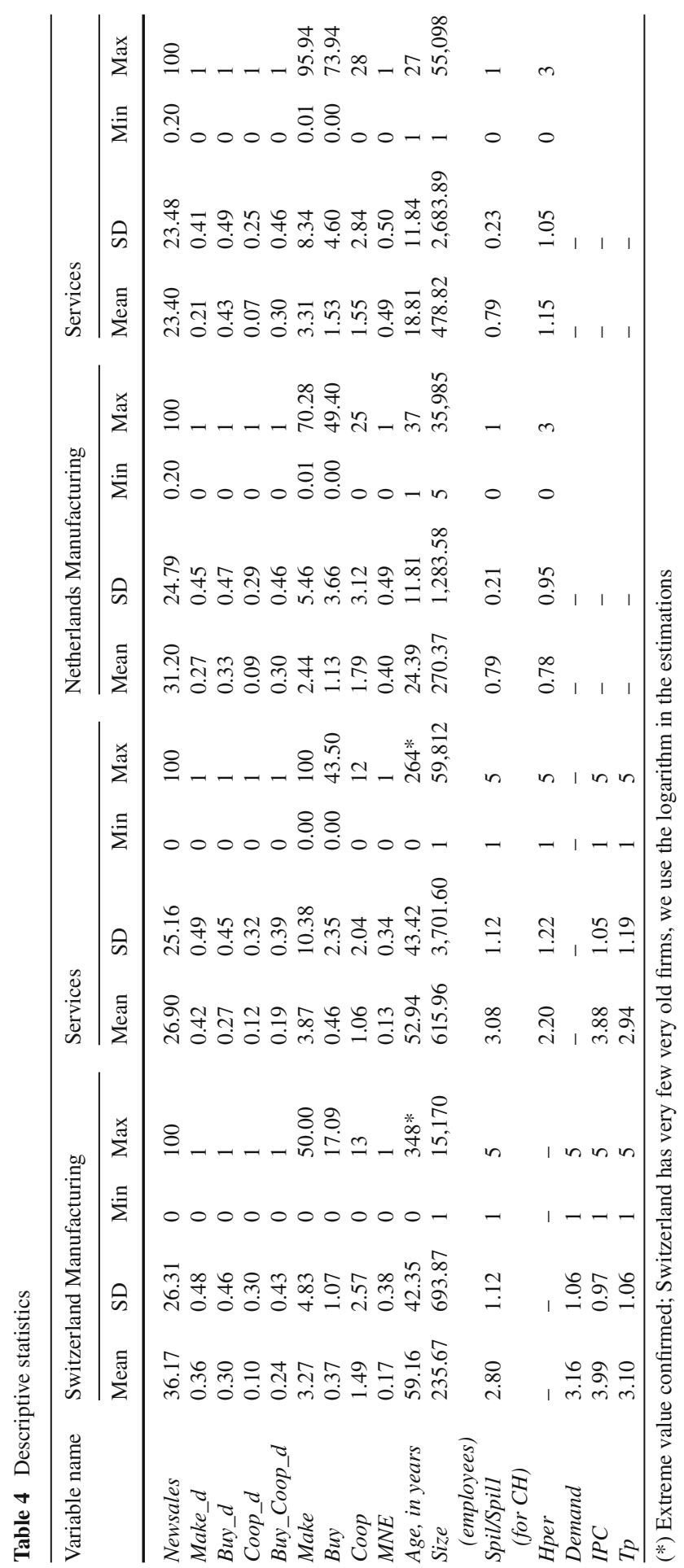




\section{Results}

In Tables 5 and 6 we report the estimation results for the specification with qualitative variables for technology acquisitions, for manufacturing (Table 5) and services (Table 6) respectively. We present two sets of estimates: in column I the estimates where the strategies are considered as exogenous; in column II those where instrumental variables are used because the strategies are considered as endogenous. ${ }^{5} \mathrm{We}$ also control for time and industry dummy variables but do not report the corresponding coefficients. ${ }^{6}$

For column II, we use the following excluded instruments: Hper, Spil, and province dummy variables for the Netherlands, and Demand, Hper, Tp, IPC, and Spill for Switzerland. Because of data unavailability, we were not able to use the same instrumental variables for the two countries. The economic justification for the instruments used in the Swiss estimations is as follows: Three of them refer to market-driven economic variables that are beyond the range of firm-driven activities: demand development (Demand), intensity of non-price competition (IPC), and the variable Hper that reflects skill shortages in the Swiss labor market that could be overcome to a large extent after 2004 through the agreements with the EU that refer to the free movement of labor between the EU countries and Switzerland. Further, the technological potential of a firm's main business activity ( $T p$ ) and spillovers (Spill) from competitors are beyond the influence of a single enterprise.

For the Netherlands the excluded instruments and their rationale are as follows. Organizational constraint (i.e., a lack of qualified personnel) is expected to relate to a 'buy' strategy as firms may outsource because they have too little personnel in-house; 'spillovers' is a measure of tacit knowledge, a reason for which firms, according to the rich managerial literature on alliances, often decide to collaborate; finally, according to numerous regional studies, clustering or proximity in geography space is an important factor that spurs firm collaboration and hence we include locational dummy variables as excluded instruments, since we expect that firms that are located in provinces that are densely populated and with many industries may be more active in engaging in collaboration because of physical proximity. These IVs should not affect innovation intensity per se and are correlated with the endogenous dummy variables.

The instruments pass various tests of the quality of the instruments: The Hansen test does not reject the hypothesis of overidentification restrictions, the Kleinberg-

\footnotetext{
5 We run regressions separately for small / medium-sized firms and large firms; high-tech and low-tech firms; and high and low R\&D intensity firms. For the Netherlands no relevant differences could be found as compared with the results for the whole sample. For Switzerland there are some additional insights: the overall positive effect for 'Make\&Buy\&Coop' ('mixed' form) can be traced back to 'large' firms; the overall effects for 'Make', 'Make squared' and 'Coop squared' can be traced back to low-tech manufacturing; finally, the overall effect of 'Buy\&Coop' can be traced back to firms with low R\&D intensity. These additional estimates are available upon request.

6 F-tests for the joint significance of industry and time dummy variables reject, with the exception of the Swiss manufacturing sector, the null hypothesis that the industry dummy variables and time dummy variables are jointly equal to zero. Moreover, we find that the coefficients of the industry dummy variables strongly correlate with the average sales share of the industries. The correlation coefficients for the manufacturing and the service industries for Switzerland are 0.95 and 0.84 respectively. For the Netherlands the respective correlation coefficients are 0.92 (manufacturing) and 0.90 (services). See also footnote 9 .
} 
Table 5 Random-effects estimation of innovation performance with qualitative indicators of knowledge acquisition, Manufacturing

\begin{tabular}{|c|c|c|c|c|}
\hline \multirow[t]{2}{*}{ Model } & \multicolumn{2}{|l|}{ Switzerland } & \multicolumn{2}{|c|}{ The Netherlands } \\
\hline & I & II & I & II \\
\hline \multicolumn{5}{|c|}{ Dependent variable: log Newsales } \\
\hline Buy_d & $\begin{array}{l}0.06 \\
(0.06)\end{array}$ & $\begin{array}{l}0.40 \\
(1.29)\end{array}$ & $\begin{array}{l}0.16^{* * * *} \\
(0.04)\end{array}$ & $\begin{array}{l}0.42 \\
(0.36)\end{array}$ \\
\hline Coop_d & $\begin{array}{l}0.03 \\
(0.08)\end{array}$ & $\begin{array}{l}-3.91 \\
(3.06)\end{array}$ & $\begin{array}{l}0.21 * * * \\
(0.06)\end{array}$ & $\begin{array}{l}0.90 \\
(0.91)\end{array}$ \\
\hline Buy_Coop_d & $\begin{array}{l}0.14 * * \\
(0.06)\end{array}$ & $\begin{array}{l}2.57 * * * \\
(0.82)\end{array}$ & $\begin{array}{l}0.26^{* * * *} \\
(0.05)\end{array}$ & $\begin{array}{l}0.56 * * \\
(0.25)\end{array}$ \\
\hline Log size & $\begin{array}{l}0.00 \\
(0.02)\end{array}$ & $\begin{array}{l}-0.16 \\
(0.06)\end{array}$ & $\begin{array}{l}0.05 \\
(0.04)\end{array}$ & $\begin{array}{l}0.03 \\
(0.05)\end{array}$ \\
\hline MNE & $\begin{array}{l}0.02 \\
(0.07)\end{array}$ & $\begin{array}{l}0.02 \\
(0.14)\end{array}$ & $\begin{array}{l}-0.01 \\
(0.04)\end{array}$ & $\begin{array}{l}-0.02 \\
(0.04)\end{array}$ \\
\hline Log age & $\begin{array}{l}-0.11 \text { *** } \\
(0.03)\end{array}$ & $\begin{array}{l}-0.06 \\
(0.07)\end{array}$ & $\begin{array}{l}-0.09 \\
(0.03)\end{array}$ & $\begin{array}{l}-0.07 * * \\
(0.03)\end{array}$ \\
\hline IMR (R\&D performing) & $\begin{array}{l}0.00 \\
(0.00)\end{array}$ & $\begin{array}{l}-0.00 \\
(0.01)\end{array}$ & $\begin{array}{l}0.39 * \\
(0.23)\end{array}$ & $\begin{array}{l}0.41 \\
(0.27)\end{array}$ \\
\hline IMR (Innovators) & & & $\begin{array}{l}0.51 \\
(0.42)\end{array}$ & $\begin{array}{l}0.43 \\
(0.39)\end{array}$ \\
\hline Intercept & $\begin{array}{l}3.26 * * * \\
(0.16)\end{array}$ & $\begin{array}{l}3.74 * * * \\
(0.58)\end{array}$ & $\begin{array}{l}2.19 * * * \\
(0.51)\end{array}$ & $\begin{array}{l}1.96^{* * * *} \\
(0.39)\end{array}$ \\
\hline$\sigma_{u}$ & 0.56 & 0.88 & 0.53 & 0.49 \\
\hline$\sigma_{e}$ & 0.83 & 1.66 & 0.81 & 0.85 \\
\hline Complementarity test & 0.26 & -1.97 & $\begin{array}{l}-0.10 \\
(0.07)\end{array}$ & -0.76 \\
\hline No of firms & 1,419 & 1,419 & 2,547 & 2,547 \\
\hline No of observations & 2,070 & 2,070 & 3,442 & 3,442 \\
\hline
\end{tabular}

$* * *$ Indicates significance at $1 \%, * *$ at $5 \%, *$ at $10 \%$ level, two-sided test. Standard errors are in parentheses. Omitted category is doing internal R\&D only (no external R\&D, no cooperation). All models include year dummy variables and industry dummy variables (13 for the Netherlands and 17 for Switzerland). The following (excluded) instruments are used in model II for the Netherlands: Spil, Hper, and province dummy variables. The following (excluded) instruments are used in model II for Switzerland: Demand, Tp, IPC, and Spil1. The null hypothesis for the complementarity test is that the coefficient of the Coop \& Buy dummy variable (doing internal and external $R \& D$ and cooperating) is equal to the sum of the coefficients of the Buy only (doing internal and external R\&D) and Coop only (doing internal R\&D and cooperating) dummy variables

Model I: The dummy variables for Buy, Coop and Coop \& Buy are not instrumented

Model II: The dummy variables for Buy, Coop and Coop \& Buy are instrumented

The IMR (Innovators) is the inverse Mills ratio for innovators obtained from a probit regression on product innovation occurrence with "being part of a group" as the excluded variable

Paap test of the null hypothesis of underidentification is rejected everywhere, except for services in the Netherlands. ${ }^{7}$ In addition, the $p$ values of the F-statistics of the first-stage regressions are close to zero. ${ }^{8}$

\footnotetext{
7 We estimated the IV models without individual effects and then with the individual effects: The former allowing us to do the tests with regard to the quality of the instruments; the latter gives us estimates of the individual effects (the estimates without individual effects are found in Tables 11 and 12, respectively in the "Appendix").

8 The estimates of the first stage equations are found in Tables 9 and 10 in the "Appendix".
} 
Table 6 Random-effects estimation of innovation performance with qualitative indicators of knowledge acquisition, Services

\begin{tabular}{|c|c|c|c|c|}
\hline \multirow[t]{2}{*}{ Model } & \multicolumn{2}{|c|}{ Switzerland } & \multicolumn{2}{|c|}{ The Netherlands } \\
\hline & I & II & I & II \\
\hline \multicolumn{5}{|c|}{ Dependent variable: log Newsales } \\
\hline Buy_d & $\begin{array}{l}0.05 \\
(0.11)\end{array}$ & $\begin{array}{l}-1.27 \\
(1.37)\end{array}$ & $\begin{array}{l}0.20 * * * \\
(0.07)\end{array}$ & $\begin{array}{l}0.98 \\
(0.83)\end{array}$ \\
\hline Coop_d & $\begin{array}{l}0.14 \\
(0.14)\end{array}$ & $\begin{array}{l}2.31 \\
(1.90)\end{array}$ & $\begin{array}{l}0.21 * \\
(0.12)\end{array}$ & $\begin{array}{l}1.62 \\
(1.47)\end{array}$ \\
\hline Buy_Coop_d & $\begin{array}{l}0.16 \\
(0.12)\end{array}$ & $\begin{array}{l}1.59 \\
(1.14)\end{array}$ & $\begin{array}{l}0.19^{* * * *} \\
(0.07)\end{array}$ & $\begin{array}{l}0.84 * \\
(0.48)\end{array}$ \\
\hline Log size & $\begin{array}{l}-0.02 \\
(0.03)\end{array}$ & $\begin{array}{l}0.01 \\
(0.06)\end{array}$ & $\begin{array}{l}-0.23^{* * *} \\
(0.03)\end{array}$ & $\begin{array}{l}-0.24 * * * \\
(0.03)\end{array}$ \\
\hline MNE & $\begin{array}{l}0.11 \\
(0.13)\end{array}$ & $\begin{array}{l}0.09 \\
(0.19)\end{array}$ & $\begin{array}{l}0.03 \\
(0.05)\end{array}$ & $\begin{array}{l}0.02 \\
(0.06)\end{array}$ \\
\hline Log age & $\begin{array}{l}-0.12^{* *} \\
(0.05)\end{array}$ & $\begin{array}{l}-0.11 \\
(0.08)\end{array}$ & $\begin{array}{l}-0.07 * \\
(0.04)\end{array}$ & $\begin{array}{l}-0.04 \\
(0.04)\end{array}$ \\
\hline IMR (R\&D performing) & $\begin{array}{l}0.18 \\
(0.13)\end{array}$ & $\begin{array}{l}0.26 \\
(0.20)\end{array}$ & $\begin{array}{l}-0.37 * * * \\
(0.09)\end{array}$ & $\begin{array}{l}-0.39 * * * \\
(0.10)\end{array}$ \\
\hline IMR (Innovators) & & & $\begin{array}{l}0.04 \\
(0.42)\end{array}$ & $\begin{array}{l}0.01 \\
(0.50)\end{array}$ \\
\hline Intercept & $\begin{array}{l}2.64 * * * \\
(0.25)\end{array}$ & $\begin{array}{l}2.32 * * * \\
(0.57)\end{array}$ & $\begin{array}{l}4.41 * * * \\
(0.28)\end{array}$ & $\begin{array}{l}3.90 * * * \\
(0.58)\end{array}$ \\
\hline$\sigma_{u}$ & 0.32 & 0.41 & 0.45 & 0.38 \\
\hline$\sigma_{e}$ & 1.05 & 1.37 & 0.91 & 0.98 \\
\hline Complementarity test & $\begin{array}{l}0.02 \\
(0.88)\end{array}$ & $\begin{array}{l}0.04 \\
(0.83)\end{array}$ & $\begin{array}{l}-0.22 \\
(0.09)\end{array}$ & $\begin{array}{l}-1.76 \\
(1.34)\end{array}$ \\
\hline No of firms & 527 & 527 & 1,574 & 1,574 \\
\hline No of observations & 669 & 669 & 1,718 & 1,718 \\
\hline
\end{tabular}

$* * *$ Indicates significance at $1 \%, * *$ at $5 \%, *$ at $10 \%$ level, two-sided test. Standard errors are in parentheses. Omitted category is Make Only (no Buy, no Coop). All models include year dummy variables and industry dummy variables (four in the Netherlands and eight in Switzerland). The following (excluded) instruments are used in model II for the Netherlands: Spil, Hper, and province dummy variables. The following (excluded) instruments are used in model II for Switzerland: Tp, Hper, IPC, and Spil1. The null hypothesis for the complementarity test is that the coefficient of the Coop \& Buy dummy variable (doing internal and external R\&D and cooperating) is equal to the sum of the coefficients of the Buy only (doing internal and external $\mathrm{R} \& \mathrm{D}$ ) and Coop only (doing internal $\mathrm{R} \& \mathrm{D}$ and cooperating) dummy variables

Model I: The dummy variables for Buy, Coop and Coop \& Buy are not instrumented

Model II: The dummy variables for Buy, Coop and Coop \& Buy are instrumented

The IMR (Innovators) is the inverse Mills ratio for innovators obtained from a probit regression on product innovation occurrence with "being part of a group" as the excluded variable.

Since the strategies are measured as exclusive dummy variables (as in Table 2), with doing internal R\&D only as the reference category, the test of complementarity consists in checking where the coefficient of the dummy variable indicating the use of all three strategies (internal, external and cooperative R\&D) is larger than the sum of the coefficients of doing internal and external R\&D and of doing internal R\&D and cooperation. Although the interaction term is always significant (and often the only significant coefficient) in both countries, we cannot reject the null hypothesis of no difference between the coefficients in line 3 and the sum of the coefficients in line 1 
and 2. The reported $p$ values of the null hypothesis of no complementarity are all larger than 0.05. Instrumenting the knowledge acquisition strategies (column II) yields less precise estimators and does not lead to significantly different results.

The intensity of product innovation is not significantly related to the size of the firm; and if it is, it is negatively related to size. This is a classic result, which can easily be explained by the fact that innovative sales increase with additional innovation input but less than the total sales of the firm. Younger enterprises are more innovative (see Schneider and Veugelers 2010), while foreign MNEs in our samples are not necessarily different from domestic firms when it comes to innovation intensity (cf. Belderbos et al. 2004; Dachs et al. 2008). The idiosyncratic component of the error term has a higher variance than the individual component. The insignificant inverse Mills ratio indicates that there is no systematic selection bias in examining only product innovators among the innovating firms.

In Table 7 we tabulate the estimation results of an error component model with individual random effects, where quantitative measures of the three sources of technology acquisition are introduced in linear, squared and interaction terms, and, as before, size, MNEs, age, the inverse Mills ratio, and time and province dummy variables are controlled for. The control variables have the same effects as in the specification with qualitative variables of technology acquisition. ${ }^{9}$

We shall concentrate on the seven coefficients that pertain to the technology acquisition variables. Although we recognize that these variables may be endogenous, we have too few good instruments to control for the endogeneity of those seven corresponding variables. Moreover, the results of Tables 4 and 5 seem to indicate that the results of IV regressions do not depart too much from those obtained without instrumenting. When we tried to estimate by IV using our small number of poor instruments, nothing became significant. As a consequence, the results should be interpreted as correlations rather than causality.

Overall, the results suggest that there are diseconomies of scale in both internal $R \& D$ and in external technology acquisition with the square terms of both $R \& D$ terms negative and significant in the Dutch data while in the Swiss sample the square terms on external technology acquisition terms are insignificant. The square term of the cooperation variable is not statistically significant in the Dutch sample, while it is positive and significant for Swiss manufacturing firms. Most of the interaction effects are not statistically significant.

Conditional on performing internal R\&D, the complementarity between Buy and Coop is given by the sum of the coefficients of the interaction terms of Buy $\times$ Coop and Buy $\times$ Make $\times$ Coop. This sum is positive in all cases, which suggests that there

\footnotetext{
9 The industry dummy variables capture the effects of industry-specific variables that we do not control for. The coefficients of those industry dummy variables reproduce the ranking of the industries in terms of the logarithms of the shares of innovative sales. In Switzerland, the shares of sales that are due to new products are particularly high in electronic and optical products, vehicles and electrical equipment (around 30\%) for manufacturing and in information technology/R\&D (29\%) and telecommunications $(21 \%)$. In the Netherlands, the sectors with the highest share of sales due to new products are machinery and equipment, office accounting and computing machinery, and motor vehicles (around $27 \%$ ) in manufacturing and environmental services $(17 \%)$ in services.
} 
Table 7 Random-effects estimation of innovation performance with quantitative indicators of knowledge acquisition

\begin{tabular}{|c|c|c|c|c|}
\hline & \multicolumn{2}{|l|}{ Switzerland } & \multicolumn{2}{|l|}{ The Netherlands } \\
\hline & Manufacturing & Services & Manufacturing & Services \\
\hline \multicolumn{5}{|c|}{ Dependent variable: log Newsales } \\
\hline Make & $\begin{array}{l}3.99 * * * \\
(1.23)\end{array}$ & $\begin{array}{l}3.48 * * \\
(1.43)\end{array}$ & $\begin{array}{l}6.96 * * * \\
(0.76)\end{array}$ & $\begin{array}{l}4.66 * * * \\
(0.75)\end{array}$ \\
\hline Make squared & $\begin{array}{l}-8.40^{* * *} \\
(4.27)\end{array}$ & $\begin{array}{l}-3.77 * * \\
(1.92)\end{array}$ & $\begin{array}{l}-11.07 * * * \\
(1.47)\end{array}$ & $\begin{array}{l}-4.26^{* * * *} \\
(1.06)\end{array}$ \\
\hline Buy & $\begin{array}{l}4.15 \\
(5.90)\end{array}$ & $\begin{array}{l}6.10 \\
(5.82)\end{array}$ & $\begin{array}{l}4.30 * * * \\
(1.04)\end{array}$ & $\begin{array}{l}4.68 * * * \\
(1.19)\end{array}$ \\
\hline External R\&D squared & $\begin{array}{l}-51.49 \\
(72.14)\end{array}$ & $\begin{array}{l}-4.26 \\
(26.96)\end{array}$ & $\begin{array}{l}-7.84 * * \\
(3.05)\end{array}$ & $\begin{array}{l}-4.60^{* * * *} \\
(1.68)\end{array}$ \\
\hline Coop & $\begin{array}{l}-0.17 \\
(0.12)\end{array}$ & $\begin{array}{l}0.24 \\
(0.23)\end{array}$ & $\begin{array}{l}0.04 * * * \\
(0.01)\end{array}$ & $\begin{array}{l}0.01 \\
(0.02)\end{array}$ \\
\hline Coop squared & $\begin{array}{l}0.13 * * \\
(0.06)\end{array}$ & $\begin{array}{l}-0.11 \\
(0.13)\end{array}$ & $\begin{array}{l}-0.00 \\
(0.00)\end{array}$ & $\begin{array}{l}0.00 \\
(0.00)\end{array}$ \\
\hline Buy $\times$ Make & $\begin{array}{l}-3.31 \\
(34.70)\end{array}$ & $\begin{array}{l}-9.94 \\
(28.51)\end{array}$ & $\begin{array}{l}-4.95 \\
(4.02)\end{array}$ & $\begin{array}{l}-13.22^{* *} \\
(5.42)\end{array}$ \\
\hline Buy $\times$ Coop & $\begin{array}{l}-4.63 \\
(4.87)\end{array}$ & $\begin{array}{l}-1.18 \\
(7.69)\end{array}$ & $\begin{array}{l}-0.61 * * * \\
(0.21)\end{array}$ & $\begin{array}{l}-0.15 \\
(0.20)\end{array}$ \\
\hline Coop $\times$ Make & $\begin{array}{l}0.13 \\
(0.72)\end{array}$ & $\begin{array}{l}-0.05 \\
(0.86)\end{array}$ & $\begin{array}{l}-0.10 \\
(0.08)\end{array}$ & $\begin{array}{l}-0.10 \\
(0.13)\end{array}$ \\
\hline Buy $\times$ Make $\times$ Coop & $\begin{array}{l}20.72 \\
(18.32)\end{array}$ & $\begin{array}{l}12.58 \\
(36.85)\end{array}$ & $\begin{array}{l}2.01 * * * \\
(0.70)\end{array}$ & $\begin{array}{l}1.36 \\
(1.30)\end{array}$ \\
\hline Log size & $\begin{array}{l}0.01 \\
(0.02)\end{array}$ & $\begin{array}{l}-0.02 \\
(0.04)\end{array}$ & $\begin{array}{l}0.01 \\
(0.04)\end{array}$ & $\begin{array}{l}-0.17 * * * \\
(0.03)\end{array}$ \\
\hline MNE & $\begin{array}{l}0.03 \\
(0.07)\end{array}$ & $\begin{array}{l}0.04 \\
(0.14)\end{array}$ & $\begin{array}{l}0.00 \\
(0.03)\end{array}$ & $\begin{array}{l}0.03 \\
(0.05)\end{array}$ \\
\hline Log age & $\begin{array}{l}-0.09 * * * \\
(0.03)\end{array}$ & $\begin{array}{l}-0.10^{*} \\
(0.05)\end{array}$ & $\begin{array}{l}-0.05^{* * *} \\
(0.02)\end{array}$ & $\begin{array}{l}-0.05 \\
(0.03)\end{array}$ \\
\hline IMR (R\&D performing) & $\begin{array}{l}-0.00 \\
(0.00)\end{array}$ & $\begin{array}{l}0.20 \\
(0.13)\end{array}$ & $\begin{array}{l}0.12 \\
(0.23)\end{array}$ & $\begin{array}{l}-0.21 * * \\
(0.09)\end{array}$ \\
\hline IMR (Innovators) & & & $\begin{array}{l}0.55 \\
(0.37)\end{array}$ & $\begin{array}{l}0.18 \\
(0.42)\end{array}$ \\
\hline Intercept & $\begin{array}{l}3.17 * * * \\
(0.16)\end{array}$ & $\begin{array}{l}2.50 * * * \\
(0.25)\end{array}$ & $\begin{array}{l}2.46 * * * \\
(0.49)\end{array}$ & $\begin{array}{l}3.85^{* * * *} \\
(0.28)\end{array}$ \\
\hline$\sigma_{u}$ & 0.56 & 0.31 & 0.39 & 0.39 \\
\hline$\sigma_{e}$ & 0.85 & 1.04 & 0.85 & 0.92 \\
\hline No of firms & 1,390 & 502 & 2,547 & 1,574 \\
\hline No of observations & 2,004 & 637 & 3,442 & 1,718 \\
\hline
\end{tabular}

*** Indicates significance at $1 \%, * *$ at $5 \%, *$ at $10 \%$ level, two-sided test. Robust standard errors are in parentheses. Random effects maximum likelihood estimator. The models for the Netherlands include 13 industry dummy variables (manufacturing subsample) and 4 service dummy variables (services subsample). The models for Switzerland include 17 industry dummy variables (manufacturing subsample) and eight industry dummy variables (services subsample)

are positive economies of scope in doing external and cooperative R\&D together. However, only in the case of manufacturing in the Netherlands is this estimate of complementarity statistically significant. 


\section{Conclusions}

Whereas prior studies have either examined the complementarity of 'make' and 'buy', or the complementarity in different types of R\&D collaboration, this study examines the complementarity between 'buy' and 'cooperate' in the presence of internal R\&D. We compare the performance of firms that are only engaged in external technology sourcing, or only in cooperative R\&D (with suppliers, customers, competitors, and research institutions) and those that combine those two open innovation strategies. Using panel data on a large set of Swiss and Dutch innovating firms, we examine whether the two open innovation strategies are complementary in fostering firm innovation.

Informed by the growing literature on open innovation, we expected that the more that firms rely on different external knowledge sourcing modes, the better they would perform in terms of innovation. While we find some evidence that both external technology sourcing and R\&D cooperation positively impact innovation in isolation, we find little evidence of an additional gain in performance when both are used simultaneously. There is no additional gain for firms in outsourcing knowledge acquisition while collaborating or vice versa. This evidence indicates that policy makers who want to increase private $R \& D$ are unlikely to succeed if they provide tax incentives for buying knowledge if $R \& D$ joint ventures are already allowed for.

There are a number of possible ways to improve the specification, which we leave for future research. First, our measure of cooperation is relatively crude, since we aggregate different types of partners (vertical, competitors, universities and research institutes) into one measure. There is some initial evidence that collaborative R\&D projects between competitors are different from collaborative projects with other types of partners, as they are broader in scope and require less complementary, simultaneous R\&D efforts from other external sources (Belderbos et al. 2012). This is one possible explanation for our difficulty in finding complementarity between 'buy' and 'cooperation' strategies.

Another possibility is to also check for complementarity in terms of other objective functions. One payoff function could be innovation in general, including all dimensions of innovation (such as process innovation, unsuccessful or uncompleted innovations). The problem here is that we have no observations on R\&D for non-innovators. Another performance criterion could be process innovation instead of product innovation, but then we could only use qualitative variables. A more economic performance criterion would be labor productivity; but in addition to data on capital stock, we might want to allow for some lag between the time when choices are made with respect to the way that technological knowledge is acquired and the time when knowledge shows up in productivity figures; hence we would require one or two more waves of innovation surveys.

Acknowledgments The fruitful comments and suggestions of two anonymous referees and the General Editor of this journal are gratefully acknowledged. 


\section{Appendix}

See Tables 8, 9, 10, 11 and 12 .

Table 8 Composition of the datasets by industry and firm size class

\begin{tabular}{|c|c|c|c|c|c|}
\hline Switzerland & Observ. & Fraction & Netherlands & Observ. & Fraction \\
\hline Manufacturing & & & Manufacturing & & \\
\hline Food/beverages/tobacco & 174 & 8.4 & Mining & 27 & 0.78 \\
\hline Textiles & 69 & 3.3 & Food/beverages/tobacco & 405 & 11.77 \\
\hline Clothing & 20 & 1.0 & Textiles and clothing & 132 & 3.83 \\
\hline Wood & 54 & 2.6 & Paper and paper products & 124 & 3.60 \\
\hline Paper & 47 & 2.3 & Printing and publishing & 143 & 4.15 \\
\hline Printing & 70 & 3.4 & Oil & 20 & 0.58 \\
\hline Chemicals & 190 & 9.2 & Chemicals & 366 & 10.63 \\
\hline Rubber/plastics & 94 & 4.5 & Rubber and plastics & 245 & 7.12 \\
\hline Non-metallic minerals & 61 & 3.0 & Basic metals & 77 & 2.24 \\
\hline Basic metals & 37 & 1.8 & Fabricated metals & 393 & 11.42 \\
\hline Fabricated metals & 214 & 10.3 & Maschinery & 577 & 16.76 \\
\hline Maschinery/equipment & 434 & 21.0 & Electrical equipment & 359 & 10.43 \\
\hline Electrical equipment & 120 & 5.8 & Transport equipment & 196 & 5.69 \\
\hline Electronic/optical products & 270 & 13.0 & Other manufacturing & 378 & 10.98 \\
\hline Watches & 78 & 3.8 & & & \\
\hline Vehicles & 33 & 1.6 & & & \\
\hline Other manufacturing & 80 & 3.9 & & & \\
\hline Energy & 25 & 1.2 & & & \\
\hline Small $(<50)$ & 698 & 33.7 & Small $(<250)$ & 2,808 & \\
\hline Medium (50-249) & 942 & 45.5 & & & \\
\hline Large $(250+)$ & 430 & 20.8 & Large $(250+)$ & 634 & \\
\hline Total manufacturing & 2,070 & 100 & Total manufacturing & 3,442 & 100 \\
\hline Services & & & Services & & \\
\hline Wholesale & 121 & 18.1 & Utilities & 322 & 18.74 \\
\hline Retail & 50 & 7.5 & Wholesale/retail/catering & 412 & 23.98 \\
\hline Accomodation/restaurants & 44 & 6.6 & Transportation/telecom. & 229 & 13.33 \\
\hline Transportation & 73 & 10.9 & Rental and leasing/IT & 710 & 41.33 \\
\hline Banks/insurance & 127 & 19.0 & Other services & 45 & 2.62 \\
\hline Real estate/rental and leasing & 6 & 0.9 & & & \\
\hline Information technology/R\&D & 81 & 12.1 & & & \\
\hline Commercial services & 155 & 23.2 & & & \\
\hline Personal services & 6 & 0.9 & & & \\
\hline Telecommunication & 5 & 0.8 & & & \\
\hline Small $(<50)$ & 300 & 44.8 & Small $(<250)$ & 1,335 & \\
\hline Medium (50-249) & 202 & & & & \\
\hline Large $(250+)$ & 167 & 25.0 & Large $(250+)$ & 383 & \\
\hline Total services & 669 & 100.0 & Total services & 1,718 & 100 \\
\hline
\end{tabular}


Table 9 First stage OLS estimates Switzerland

\begin{tabular}{|c|c|c|c|c|c|c|}
\hline & \multicolumn{3}{|c|}{ Manufacturing } & \multicolumn{3}{|l|}{ Services } \\
\hline & Buy_d & Coop_d & Buy_Coop_d & Buy_d & Coop_d & Buy_Coop_d \\
\hline Log size & $\begin{array}{l}0.062 * \\
(0.033)\end{array}$ & $\begin{array}{l}-0.003 \\
(0.038)\end{array}$ & $\begin{array}{l}0.167 * * * \\
(0.032)\end{array}$ & $\begin{array}{l}0.111 * * \\
(0.047)\end{array}$ & $\begin{array}{l}-0.053 \\
(0.063)\end{array}$ & $\begin{array}{l}0.105 * * \\
(0.052)\end{array}$ \\
\hline MNE & $\begin{array}{l}0.092 \\
(0.079)\end{array}$ & $\begin{array}{l}0.045 \\
(0.105)\end{array}$ & $\begin{array}{l}0.04 \\
(0.084)\end{array}$ & $\begin{array}{l}-0.017 \\
(0.164)\end{array}$ & $\begin{array}{l}-0.083 \\
(0.203)\end{array}$ & $\begin{array}{l}-0.003 \\
(0.174)\end{array}$ \\
\hline Log Age & $\begin{array}{l}-0.049 \\
(0.038)\end{array}$ & $\begin{array}{l}0.066 \\
(0.052)\end{array}$ & $\begin{array}{l}0.054 \\
(0.042)\end{array}$ & $\begin{array}{l}-0.013 \\
(0.063)\end{array}$ & $\begin{array}{l}0.105 \\
(0.086)\end{array}$ & $\begin{array}{l}-0.110 \\
(0.072)\end{array}$ \\
\hline IMR & $\begin{array}{l}-0.034 * * \\
(0.016)\end{array}$ & $\begin{array}{l}-0.011 \\
(0.012)\end{array}$ & $\begin{array}{l}0.014 \\
(0.009)\end{array}$ & $\begin{array}{l}-0.132 \\
(0.218)\end{array}$ & $\begin{array}{l}-0.341 \\
(0.345)\end{array}$ & $\begin{array}{l}-0.100 \\
(0.230)\end{array}$ \\
\hline $\mathrm{Tp}$ & $\begin{array}{l}0.02 \\
(0.029)\end{array}$ & $\begin{array}{l}0.046 \\
(0.039)\end{array}$ & $\begin{array}{l}0.182^{* * * *} \\
(0.033)\end{array}$ & $\begin{array}{l}-0.082^{*} \\
(0.049)\end{array}$ & $\begin{array}{l}0.134 * * \\
(0.062)\end{array}$ & $\begin{array}{l}0.079 \\
(0.055)\end{array}$ \\
\hline Demand & $\begin{array}{l}0.002 \\
(0.029)\end{array}$ & $\begin{array}{l}-0.007 \\
(0.037)\end{array}$ & $\begin{array}{l}0.126^{* * * *} \\
(0.032)\end{array}$ & & & \\
\hline Hper & & & & $\begin{array}{l}0.128 * * \\
(0.062)\end{array}$ & $\begin{array}{l}0.010 \\
(0.087)\end{array}$ & $\begin{array}{l}0.115^{*} \\
(0.069)\end{array}$ \\
\hline IPC & $\begin{array}{l}-0.004 \\
(0.031)\end{array}$ & $\begin{array}{l}0.097 * * \\
(0.043)\end{array}$ & $\begin{array}{l}0.056 \\
(0.035)\end{array}$ & $\begin{array}{l}-0.089 * \\
(0.051)\end{array}$ & $\begin{array}{l}0.100 \\
(0.065)\end{array}$ & $\begin{array}{l}-0.141^{* *} \\
(0.056)\end{array}$ \\
\hline Spil1 & $\begin{array}{l}0.095 * * * \\
(0.027)\end{array}$ & $\begin{array}{l}-0.062 * \\
(0.035)\end{array}$ & $\begin{array}{l}-0.039 \\
(0.029)\end{array}$ & $\begin{array}{l}-0.026 \\
(0.050)\end{array}$ & $\begin{array}{l}-0.147 \text { ** } \\
(0.060)\end{array}$ & $\begin{array}{l}0.140 * * * \\
(0.054)\end{array}$ \\
\hline IMR & $\begin{array}{l}-0.034 * * \\
(0.016)\end{array}$ & $\begin{array}{l}-0.011 \\
(0.012)\end{array}$ & $\begin{array}{l}0.014 \\
(0.009)\end{array}$ & $\begin{array}{l}-0.132 \\
(0.218)\end{array}$ & $\begin{array}{l}-0.341 \\
(0.345)\end{array}$ & $\begin{array}{l}-0.100 \\
(0.230)\end{array}$ \\
\hline _cons & $\begin{array}{l}-1.068 * * * \\
(0.269)\end{array}$ & $\begin{array}{l}-1.900 * * * \\
(0.366)\end{array}$ & $\begin{array}{l}-3.057 * * * \\
(0.304)\end{array}$ & $\begin{array}{l}-0.582 \\
(0.400)\end{array}$ & $\begin{array}{l}-1.581 * * * \\
(0.529)\end{array}$ & $\begin{array}{l}-1.412 \text { *** } \\
(0.449)\end{array}$ \\
\hline Number of observations & 2,070 & 2,070 & 2,070 & 669 & 657 & 663 \\
\hline Wald $\chi^{2}$ & $54.12 * * *$ & $63.45^{* * *}$ & $243.03 * * *$ & $32.39 * *$ & $25.56^{*}$ & $54.28 * * *$ \\
\hline
\end{tabular}

$* * *$ Indicates significance at $1 \%, * *$ at $5 \%, *$ at $10 \%$ level, two-sided test. Standard errors are in parentheses. All models include 2 year dummy variables $(2002,2005)$ and industry dummy variables (17 for the manufacturing sector and 8 for the service sector)

Table 10 First stage OLS estimates Netherlands

\begin{tabular}{|c|c|c|c|c|c|c|}
\hline & \multicolumn{3}{|c|}{ Manufacturing } & \multicolumn{3}{|l|}{ Services } \\
\hline & Buy_d & Coop_d & Buy_Coop_d & Buy_d & Coop_d & Buy_Coop_d \\
\hline Log size & $\begin{array}{l}0.018 \\
(0.021)\end{array}$ & $\begin{array}{l}-0.009 \\
(0.013)\end{array}$ & $\begin{array}{l}0.046 * * \\
(0.019)\end{array}$ & $\begin{array}{l}-0.021 * \\
(0.012)\end{array}$ & $\begin{array}{l}-0.000 \\
(0.006)\end{array}$ & $\begin{array}{l}0.048 * * * \\
(0.011)\end{array}$ \\
\hline MNE & $\begin{array}{l}-0.002 \\
(0.018)\end{array}$ & $\begin{array}{l}0.020^{*} \\
(0.012)\end{array}$ & $\begin{array}{l}0.001 \\
(0.017)\end{array}$ & $\begin{array}{l}-0.015 \\
(0.024)\end{array}$ & $\begin{array}{l}0.026 * * \\
(0.013)\end{array}$ & $\begin{array}{l}-0.037^{*} \\
(0.022)\end{array}$ \\
\hline Log Age & $\begin{array}{l}0.025^{* *} \\
(0.012)\end{array}$ & $\begin{array}{l}-0.015^{*} \\
(0.008)\end{array}$ & $\begin{array}{l}-0.034 * * * \\
(0.010)\end{array}$ & $\begin{array}{l}0.000 \\
(0.014)\end{array}$ & $\begin{array}{l}-0.006 \\
(0.008)\end{array}$ & $\begin{array}{l}-0.021 \\
(0.013)\end{array}$ \\
\hline IMR (R\&D) & $\begin{array}{l}0.324 * * * \\
(0.115)\end{array}$ & $\begin{array}{l}-0.030 \\
(0.073)\end{array}$ & $\begin{array}{l}-0.239 * * \\
(0.104)\end{array}$ & $\begin{array}{l}0.058 \\
(0.044)\end{array}$ & $\begin{array}{l}-0.022 \\
(0.023)\end{array}$ & $\begin{array}{l}-0.001 \\
(0.040)\end{array}$ \\
\hline IMR (Innovator) & $\begin{array}{l}-0.160 \\
(0.267)\end{array}$ & $\begin{array}{l}-0.049 \\
(0.167)\end{array}$ & $\begin{array}{l}0.161 \\
(0.241)\end{array}$ & $\begin{array}{l}0.772 * * \\
(0.368)\end{array}$ & $\begin{array}{l}0.282 \\
(0.193)\end{array}$ & $\begin{array}{l}0.683 \\
(0.333)\end{array}$ \\
\hline Hper & $\begin{array}{l}0.012 \\
(0.009)\end{array}$ & $\begin{array}{l}-0.008 \\
(0.006)\end{array}$ & $\begin{array}{l}0.037 * * * \\
(0.008)\end{array}$ & $\begin{array}{l}0.016 \\
(0.011)\end{array}$ & $\begin{array}{l}-0.013^{* *} \\
(0.006)\end{array}$ & $\begin{array}{l}0.040 * * * \\
(0.011)\end{array}$ \\
\hline Spil & $\begin{array}{l}-0.151 * * * \\
(0.038)\end{array}$ & $\begin{array}{l}0.043 * * \\
(0.023)\end{array}$ & $\begin{array}{l}-0.293 * * * \\
(0.034)\end{array}$ & $\begin{array}{l}0.227 * * \\
(0.051)\end{array}$ & $\begin{array}{l}0.027 \\
(0.027)\end{array}$ & $\begin{array}{l}-0.322^{* * * *} \\
(0.047)\end{array}$ \\
\hline Friesland & $\begin{array}{l}0.024 \\
(0.046)\end{array}$ & $\begin{array}{l}-0.011 \\
(0.029)\end{array}$ & $\begin{array}{l}0.010 \\
(0.042)\end{array}$ & $\begin{array}{l}-0.005 \\
(0.095)\end{array}$ & $\begin{array}{l}0.005 \\
(0.050)\end{array}$ & $\begin{array}{l}-0.024 \\
(0.086)\end{array}$ \\
\hline
\end{tabular}


Table 10 continued

\begin{tabular}{|c|c|c|c|c|c|c|}
\hline & \multicolumn{3}{|c|}{ Manufacturing } & \multicolumn{3}{|l|}{ Services } \\
\hline & Buy_d & Coop_d & Buy_Coop_d & Buy_d & Coop_d & Buy_Coop_d \\
\hline Drenthe & $\begin{array}{l}-0.035 \\
(0.059)\end{array}$ & $\begin{array}{l}-0.082 * * \\
(0.037)\end{array}$ & $\begin{array}{l}0.058 \\
(0.053)\end{array}$ & $\begin{array}{l}0.024 \\
(0.118)\end{array}$ & $\begin{array}{c}-0.051 \\
(0.062)\end{array}$ & $\begin{array}{l}0.033 \\
(0.107)\end{array}$ \\
\hline Overijssel & $\begin{array}{l}-0.030 \\
(0.036)\end{array}$ & $\begin{array}{l}0.000 \\
(0.023)\end{array}$ & $\begin{array}{l}0.004 \\
(0.032)\end{array}$ & $\begin{array}{c}-0.005 \\
(0.058)\end{array}$ & $\begin{array}{l}-0.013 \\
(0.031)\end{array}$ & $\begin{array}{l}-0.045 \\
(0.053)\end{array}$ \\
\hline Flevoland & $\begin{array}{l}0.227 * * \\
0.068\end{array}$ & $\begin{array}{l}-0.060 \\
(0.043)\end{array}$ & $\begin{array}{l}-0.091 \\
(0.061)\end{array}$ & $\begin{array}{l}0.039 \\
(0.088)\end{array}$ & $\begin{array}{l}-0.042 \\
(0.046)\end{array}$ & $\begin{array}{l}-0.054 \\
(0.079)\end{array}$ \\
\hline Gelderland & $\begin{array}{l}0.001 \\
(0.038)\end{array}$ & $\begin{array}{l}-0.015 \\
(0.024)\end{array}$ & $\begin{array}{l}0.002 \\
(0.034)\end{array}$ & $\begin{array}{l}-0.020 \\
(0.049)\end{array}$ & $\begin{array}{l}-0.050 * \\
(0.026)\end{array}$ & $\begin{array}{l}0.031 \\
(0.045)\end{array}$ \\
\hline Utrecht & $\begin{array}{l}0.088 * * \\
(0.046)\end{array}$ & $\begin{array}{l}-0.061 \\
(0.028)\end{array}$ & $\begin{array}{l}-0.052 \\
(0.041)\end{array}$ & $\begin{array}{l}-0.120 * * \\
(0.060)\end{array}$ & $\begin{array}{l}0.040 \\
(0.031)\end{array}$ & $\begin{array}{l}0.054 \\
(0.055)\end{array}$ \\
\hline Nord Holland & $\begin{array}{l}-0.038 \\
(0.039)\end{array}$ & $\begin{array}{l}-0.031 \\
(0.023)\end{array}$ & $\begin{array}{l}0.045 \\
(0.034)\end{array}$ & $\begin{array}{l}-0.006 \\
(0.045)\end{array}$ & $\begin{array}{l}-0.022 \\
(0.023)\end{array}$ & $\begin{array}{l}0.055 \\
(0.040)\end{array}$ \\
\hline Zuid Holland & $\begin{array}{l}-0.029 \\
(0.034)\end{array}$ & $\begin{array}{l}-0.037 * \\
(0.021)\end{array}$ & $\begin{array}{l}0.005 \\
(0.031)\end{array}$ & $\begin{array}{l}0.061 \\
(0.047)\end{array}$ & $\begin{array}{l}0.009 \\
(0.025)\end{array}$ & $\begin{array}{l}0.053 \\
(0.043)\end{array}$ \\
\hline Zeeland & $\begin{array}{l}0.161 * * \\
(0.071)\end{array}$ & $\begin{array}{l}-0.013 \\
(0.044)\end{array}$ & $\begin{array}{c}-0.098 \\
(0.064)\end{array}$ & $\begin{array}{c}-0.054 \\
(0.132)\end{array}$ & $\begin{array}{l}0.033 \\
(0.069)\end{array}$ & $\begin{array}{l}0.062 \\
(0.119)\end{array}$ \\
\hline Nord Brabant & $\begin{array}{l}0.006 \\
(0.029)\end{array}$ & $\begin{array}{l}0.001 \\
(0.018)\end{array}$ & $\begin{array}{l}0.011 \\
(0.026)\end{array}$ & $\begin{array}{c}-0.050 \\
(0.064)\end{array}$ & $\begin{array}{l}0.015 \\
(0.034)\end{array}$ & $\begin{array}{l}0.081 \\
(0.058)\end{array}$ \\
\hline Limburg & $\begin{array}{l}0.034 \\
(0.035)\end{array}$ & $\begin{array}{l}-0.011 \\
(0.022)\end{array}$ & $\begin{array}{l}0.010 \\
(0.032)\end{array}$ & $\begin{array}{c}-0.087 \\
(0.068)\end{array}$ & $\begin{array}{l}-0.009 \\
(0.036)\end{array}$ & $\begin{array}{l}0.095 \\
(0.062)\end{array}$ \\
\hline _cons & $\begin{array}{l}0.068 \\
(0.265)\end{array}$ & $\begin{array}{l}0.305^{*} \\
(0.166)\end{array}$ & $\begin{array}{l}0.454^{*} \\
(0.239)\end{array}$ & $\begin{array}{l}0.296^{*} \\
(0.159)\end{array}$ & $\begin{array}{l}0.137 \\
(0.083)\end{array}$ & $\begin{array}{l}0.140 \\
(0.144)\end{array}$ \\
\hline Number of observations & 3,442 & 3,442 & 3,442 & 1,718 & 1,718 & 1,718 \\
\hline Wald $\chi^{2}$ & $267 * * *$ & $106 * * *$ & $756 * * *$ & $176^{* * *}$ & $45^{* *}$ & $264 * * *$ \\
\hline
\end{tabular}

$* * *$ Indicates significance at $1 \%, * *$ at $5 \%, *$ at $10 \%$ level, two-sided test. Standard errors are in parentheses. All models include 2 year dummy variables $(2002,2005)$ and industry dummy variables (13 for the manufacturing sector and 4 for the service sector)

Table 11 Models without individual effects (qualitative indicators)

\begin{tabular}{|c|c|c|c|c|}
\hline & \multicolumn{2}{|l|}{ Switzerland } & \multicolumn{2}{|l|}{ The Netherlands } \\
\hline & Manufacturing & Services & Manufacturing & Services \\
\hline Buy_d & $\begin{array}{l}0.204 \\
(1.271)\end{array}$ & $\begin{array}{l}-1.090 \\
(1.263)\end{array}$ & $\begin{array}{l}0.42 \\
(0.34)\end{array}$ & $\begin{array}{l}1.03 \\
(0.87)\end{array}$ \\
\hline Coop_d & $\begin{array}{l}-3.475 \\
(2.663)\end{array}$ & $\begin{array}{l}2.226 \\
(1.693)\end{array}$ & $\begin{array}{l}0.86 \\
(0.85)\end{array}$ & $\begin{array}{l}1.81 \\
(1.54)\end{array}$ \\
\hline Buy_Coop_d & $\begin{array}{l}2.476 * * * \\
(0.759)\end{array}$ & $\begin{array}{l}1.540 \\
(1.075)\end{array}$ & $\begin{array}{l}0.55^{* *} \\
(0.24)\end{array}$ & $\begin{array}{l}1.04 * \\
(0.50)\end{array}$ \\
\hline Log Size & $\begin{array}{l}-0.150 * * * \\
(0.058)\end{array}$ & $\begin{array}{l}-0.003 \\
(0.055)\end{array}$ & $\begin{array}{l}0.05 \\
(0.04)\end{array}$ & $\begin{array}{l}-0.07 \\
(0.08)\end{array}$ \\
\hline MNE & $\begin{array}{l}0.011 \\
(0.135)\end{array}$ & $\begin{array}{l}0.098 \\
(0.198)\end{array}$ & $\begin{array}{l}-0.03 \\
(0.04)\end{array}$ & $\begin{array}{l}-0.05 \\
(0.07)\end{array}$ \\
\hline Log age & $\begin{array}{l}-0.076 \\
(0.056)\end{array}$ & $\begin{array}{l}-0.109 \\
(0.072)\end{array}$ & $\begin{array}{l}-0.06^{* *} \\
(0.03)\end{array}$ & $\begin{array}{l}-0.04 \\
(0.04)\end{array}$ \\
\hline IMR (R\&D) & $\begin{array}{l}-0.005 \\
(0.006)\end{array}$ & $\begin{array}{l}0.261 \\
(0.197)\end{array}$ & $\begin{array}{l}0.48^{*} \\
(0.26)\end{array}$ & $\begin{array}{l}0.50 \\
(0.42)\end{array}$ \\
\hline
\end{tabular}


Table 11 continued

\begin{tabular}{|c|c|c|c|c|}
\hline & \multicolumn{2}{|l|}{ Switzerland } & \multicolumn{2}{|l|}{ The Netherlands } \\
\hline & Manufacturing & Services & Manufacturing & Services \\
\hline IMR (Innovators) & & & $\begin{array}{l}0.40 \\
(0.41)\end{array}$ & $\begin{array}{l}0.08 \\
(0.46)\end{array}$ \\
\hline _cons & $\begin{array}{l}3.725 * * * \\
(0.537)\end{array}$ & $\begin{array}{l}2.311 * * * \\
(0.519)\end{array}$ & $\begin{array}{l}2.17 * * * \\
(0.48)\end{array}$ & $\begin{array}{l}1.37 \\
(1.40)\end{array}$ \\
\hline Number of observations & 2,070 & 669 & 3,442 & 1,718 \\
\hline $\mathrm{F}$ & $3.71 * * *$ & $3.36^{* * * *}$ & $16.21 * * *$ & $13.53 * * *$ \\
\hline
\end{tabular}

$* * *$ Indicates significance at $1 \%, * *$ at $5 \%, *$ at $10 \%$ level, two-sided test. Standard errors are in parentheses. For Switzerland: all models include 2 year dummy variables $(2002,2005)$ and industry dummy variables (17 for the manufacturing sector and 8 for the service sector). For the Netherlands 13 industry dummy variables (manufacturing sub-sample) and 4 service dummy variables (services sub-sample)

Table 12 Models without individual effects (quantitative indicators)

\begin{tabular}{|c|c|c|c|c|}
\hline & \multicolumn{2}{|l|}{ Switzerland } & \multicolumn{2}{|l|}{ The Netherlands } \\
\hline & Manufacturing & Services & Manufacturing & Services \\
\hline Make & $\begin{array}{l}4.195 * * * \\
(1.246)\end{array}$ & $\begin{array}{l}3.528 * * \\
(1.460)\end{array}$ & $\begin{array}{l}7.083^{* * * *} \\
(0.689)\end{array}$ & $\begin{array}{l}4.688 * * * \\
(0.785)\end{array}$ \\
\hline Make squared & $\begin{array}{l}-8.916^{* *} \\
(4.304)\end{array}$ & $\begin{array}{l}-3.809 * \\
(1.964)\end{array}$ & $\begin{array}{l}-11.208 * * * \\
(2.549)\end{array}$ & $\begin{array}{l}-4.251 * * * \\
(1.122)\end{array}$ \\
\hline Buy & $\begin{array}{l}5.031 \\
(5.992)\end{array}$ & $\begin{array}{l}6.136 \\
(5.944)\end{array}$ & $\begin{array}{l}4.618 * * * \\
(0.985)\end{array}$ & $\begin{array}{l}4.693 * * * \\
(1.198)\end{array}$ \\
\hline Buy squared & $\begin{array}{l}-50.613 \\
(72.847)\end{array}$ & $\begin{array}{l}-4.394 \\
(27.554)\end{array}$ & $\begin{array}{l}-8.564 * * * \\
(3.067)\end{array}$ & $\begin{array}{l}-4.650^{* * * *} \\
(1.691)\end{array}$ \\
\hline Coop & $\begin{array}{l}-0.214^{*} \\
(0.118)\end{array}$ & $\begin{array}{l}0.231 \\
(0.238)\end{array}$ & $\begin{array}{l}0.046^{* * * *} \\
(0.012)\end{array}$ & $\begin{array}{l}0.011 \\
(0.017)\end{array}$ \\
\hline Coop squared & $\begin{array}{l}0.150 * * \\
(0.060)\end{array}$ & $\begin{array}{l}-0.101 \\
(0.129)\end{array}$ & $\begin{array}{l}-0.001 \\
(0.001)\end{array}$ & $\begin{array}{l}0.001 \\
(0.001)\end{array}$ \\
\hline Buy $\times$ Make & $\begin{array}{l}1.554 \\
(35.066)\end{array}$ & $\begin{array}{l}-10.005 \\
(29.131)\end{array}$ & $\begin{array}{l}-5.149 \\
(5.375)\end{array}$ & $\begin{array}{l}-13.313^{* *} \\
(5.378)\end{array}$ \\
\hline Buy $\times$ Coop & $\begin{array}{l}-4.839 \\
(5.029)\end{array}$ & $\begin{array}{l}-1.147 \\
(7.832)\end{array}$ & $\begin{array}{l}-0.608 * * * \\
(0.224)\end{array}$ & $\begin{array}{l}-0.154 \\
(0.200)\end{array}$ \\
\hline Coop $\times$ Make & $\begin{array}{l}0.322 \\
(0.747)\end{array}$ & $\begin{array}{l}-0.053 \\
(0.876)\end{array}$ & $\begin{array}{l}-0.103 \\
(0.094)\end{array}$ & $\begin{array}{l}-0.097 \\
(0.126)\end{array}$ \\
\hline Make $\times$ Buy $\times$ Coop & $\begin{array}{l}19.229 \\
(18.611)\end{array}$ & $\begin{array}{l}12.810 \\
(37.688)\end{array}$ & $\begin{array}{l}1.952 * * * \\
(0.675)\end{array}$ & $\begin{array}{l}1.372 \\
(1.319)\end{array}$ \\
\hline Log size & $\begin{array}{l}0.006 \\
(0.020)\end{array}$ & $\begin{array}{l}-0.019 \\
(0.035)\end{array}$ & $\begin{array}{l}0.014 \\
(0.041)\end{array}$ & $\begin{array}{l}-0.168 * * * \\
(0.025)\end{array}$ \\
\hline MNE & $\begin{array}{l}0.029 \\
(0.063)\end{array}$ & $\begin{array}{l}0.044 \\
(0.138)\end{array}$ & $\begin{array}{l}-0.001 \\
(0.036)\end{array}$ & $\begin{array}{l}0.028 \\
(0.052)\end{array}$ \\
\hline Log age & $\begin{array}{l}-0.092 * * * \\
(0.030)\end{array}$ & $\begin{array}{l}-0.100^{*} \\
(0.052)\end{array}$ & $\begin{array}{l}-0.047 * * \\
(0.023)\end{array}$ & $\begin{array}{l}-0.046 \\
(0.034)\end{array}$ \\
\hline IMR (R\&D) & $\begin{array}{l}-0.001 \\
(0.003)\end{array}$ & $\begin{array}{l}0.209 \\
(0.132)\end{array}$ & $\begin{array}{l}0.124 \\
(0.231)\end{array}$ & $\begin{array}{l}-0.217 * * \\
(0.090)\end{array}$ \\
\hline IMR (Innovator) & & & $\begin{array}{l}0.520 \\
(0.390)\end{array}$ & $\begin{array}{l}0.198 \\
(0.414)\end{array}$ \\
\hline
\end{tabular}


Table 12 continued

\begin{tabular}{|c|c|c|c|c|}
\hline & \multicolumn{2}{|l|}{ Switzerland } & \multicolumn{2}{|l|}{ The Netherlands } \\
\hline & Manufacturing & Services & Manufacturing & Services \\
\hline _cons & $\begin{array}{l}3.172 * * * \\
(0.155)\end{array}$ & $\begin{array}{l}2.501 * * * \\
(0.259)\end{array}$ & $\begin{array}{l}2.452 * * * \\
(0.487)\end{array}$ & $\begin{array}{l}3.847 * * * \\
(0.280)\end{array}$ \\
\hline Number of observations & 2,004 & 637 & 3,442 & 1,718 \\
\hline $\mathrm{F}$ & $8.58 * * *$ & $4.46^{* * *}$ & $21.05 * * *$ & 20.91 \\
\hline $\mathrm{R}^{2}$ & 0.13 & 0.15 & 0.15 & 0.17 \\
\hline
\end{tabular}

*** Indicates significance at $1 \%, * *$ at $5 \%, *$ at $10 \%$ level, two-sided test. Standard errors are in parentheses. For Switzerland: all models include 2 year dummy variables $(2002,2005)$ and industry dummy variables (17 for the manufacturing sector and 8 for the service sector). For the Netherlands: 13 industry dummy variables (manufacturing subsample) and 4 service dummy variables (services subsample)

\section{References}

Adams, J. D., \& Marcu, M. (2004). R\&D sourcing, joint ventures and innovation: A multiple indicators approach. NBER Working Paper No. 10474, Cambridge, MA.

Arvanitis, S., Kubli, U., \& Woerter, M. (2011). Knowledge and technology transfer activities between firms and universities in Switzerland: An analysis based on firm data. Industry and Innovation, 18(4), 369-392.

Athey, S., \& Stern, S. (1998). An empirical framework for testing theories about complementarity in organizational design. NBER Working Paper 6600, Cambridge, MA.

Belderbos, R., Carree, M., \& Lokshin, B. (2006). Complementarity in R\&D cooperation strategies. Review of Industrial Organization, 28, 401-426.

Belderbos, R., Carree, M., \& Lokshin, B. (2004). Cooperative R\&D and firm performance. Research Policy, 33, 1477-1492.

Belderbos, R., Gilsing, V., \& Lokshin, B. (2012). Persistence of and interrelation between horizontal and vertical technology alliances. Journal of Management, 38(6), 1788-1811.

Beneito, P. (2006). The innovative performance of in-house and contracted R\&D in terms of patents and utility models. Research Policy, 35, 502-517.

Bönte, W. (2003). R\&D and productivity: Internal vs. external R\&D_Evidence from West German manufacturing industries. Economics of Innovation and New Technology, 12(4), 343-360.

Carree, M., Loksin, B., \& Belderbos, R. (2011). A note on testing for complementarity and substitutability in the case of multiple practices. Journal of Productivity Analysis, 35, 263-269.

Cassiman, B., \& Veugelers, R. (2002). R\&D cooperation and spillovers: Some empirical evidence from Belgium. American Economic Review, 92(4), 1169-1184.

Cassiman, B., \& Veugelers, R. (2006). In search of complementarity in innovation strategy: Internal R\&D, cooperation in R\&D and external technology acquisition. Management Science, 52(1), 68-82.

Ceccagnoli, M., Higgins, M.J., \& Palermo, V. (2013). Behind the scenes: Sources of complementarity in R\&D. NBER Working Paper No. 18795, Cambridge, Mass.

Chesbrough, H. W. (2003). Open Innovation: The new imperative for creating and profiting from technology. Boston, MA: Harvard Business School Press.

Cincera, M., Lieselot, K., van Pottelsberghe, B., \& Veugelers, R. (2003). Productivity, R\&D and the role of international collaborative agreements. Brussels Economic Review/Cahiers Economiques de Bruxelles, 46(3), 107-140.

Cohen, W. M., \& Levinthal, D. A. (1989). Innovation and learning: The two faces of R\&D. Economic Journal, 99, 569-596.

Cohen, W. M., \& Levinthal, D. A. (1990). Absorptive capacity: A new perspective on learning and innovation. Administrative Science Quarterly, 35, 128-152.

Dachs, B., Ebersberger, B., \& Lööf, H. (2008). The innovative performance of foreign-owned enterprises in small open economies. Journal of Technology Transfer, 33, 393-406.

Dahlander, L., \& Gann, D. M. (2010). How open is innovation? Research Policy, 39, 699-709. 
De Bondt, R. (1996). Spillovers and innovative activities. International Journal of Industrial Organization, $15,1-28$.

Drechsler, W., \& Natter, M. (2012). Understanding a firm's openness decisions in innovation. Journal of Business Research, 65, 438-445.

Fey, C. F., \& Birkinshaw, J. (2005). External sources of knowledge, governance mode, and R\&D performance. Journal of Management, 31(4), 597-621.

Fritsch, M., \& Meschede, M. (2001). Product innovation, process innovation, and size. Review of Industrial Organization, 19, 335-350.

Grimpe, C., \& Hussinger, K. (2013). Formal and informal technology transfer from academia to industry: Complementary effects and innovation performance. Industry and Innovation, 20(8), 683-700.

Hagedoorn, J., \& Wang, N. (2012). Is there complementarity or substitutability between internal and external R\&D strategies. Research Policy, 41(6), 1072-1083.

Leiponen, A. (2005). Core complementarities of the corporation: Organization of an innovating firm. Managerial and Decision Economics, 26, 351-365.

Lokshin, B., Belderbos, R., \& Carree, M. (2008). The productivity effects of internal and external R\&D: Evidence from a dynamic panel data model. Oxford Bulletin of Economics and Statistics, 70(3), 399-413.

Milgrom, P., \& Roberts, J. (1990). The economics of modern manufacturing: Technology, strategy and organization. American Economic Review, 80(3), 511-528.

Miravete, E., \& Pernías, J. (2006). Innovation complementarity and scale of production. Journal of Industrial Economics, 54, 1-29.

Pavitt, K., Robson, M., \& Townsend, J. (1987). The size distribution of innovation firms in the UK: 19451983. Journal of Industrial Economics, 35, 291-316.

Peeters, C., \& van Pottelsberghe de la Potterie, B. (2006). Innovation strategy and the patenting behaviour of firms. Journal of Evolutionary Economics, 16, 109-135.

Scherer, F. M. (1984). Using linked patent and R\&D data to measure interindustry technology flows. In Z. Griliches (Ed.), $R \& D$ patents and productivity. Chicago: University of Chicago Press.

Scherer, F. M. (1991). Changing perspectives in the firm size problem. In Z. J. Acs \& D. B. Audretsch (Eds.), Innovation and technological change-An international perspective. New York: Harvester Wheatsheaf.

Schmiedeweg, C. (2008). Complementarities of innovation activities: An empirical analysis of the German manufacturing sector. Research Policy, 37, 1492-1503.

Schneider, C., \& Veugelers, R. (2010). On young highly innovative companies: Why they matter and how (not) to policy support them. Industrial and Corporate Change, 19(4), 969-1007.

Williamson, O. E. (1975). Markets and hierarchies: Analysis and antitrust implications. New York: Free Press.

Woerter, M. (2011). Driving forces for research and development strategies. Economics of Innovation and New Technology, 20(7), 611-636. 